\title{
Microbial Fuel Cells for Nitrate Removal in Ground Water
}

\author{
Xiao Xiao*, Kangping Cui \\ Department of Resources and Environmental Engineering, Hefei University of Technology, Hefei, China \\ Email: alleyxx123@gmail.com
}

Received 28 May 2015; accepted 20 June 2015; published 23 June 2015

Copyright (C) 2015 by authors and Scientific Research Publishing Inc.

This work is licensed under the Creative Commons Attribution International License (CC BY). http://creativecommons.org/licenses/by/4.0/

c) (i) Open Access

\section{Abstract}

The increasing nitrate concentration in groundwater has become a serious concern all over the world. In this study, the double chamber microbial fuel cell (MFC) and single chamber MFC systems were proposed for simultaneous removal of chemical oxygen demand (COD) and nitrate $\left(\mathrm{NO}_{3}^{-}-\mathrm{N}\right.$ ).Transforming the various variables (cathod materials, external resistance and initial concentrations of $\mathrm{NO}_{3}^{-}-\mathrm{N}$ ) of double chamber MFC to determine the optimal operating parameters. Observing the treatment effect of single chamber MFC when adding an external resistance. The results showed: in the case of connecting external circuit, the double chamber MFC could reach the best degradation effect of $\mathrm{NO}_{3}^{-}-\mathrm{N}$ and COD when cathode and anode materials are made of stainless steel velvet, the external resistance of $100 \Omega$ and the initial concentrations of $\mathrm{NO}_{3}^{-}-\mathrm{N}$ of around $250 \mathrm{mg} / \mathrm{L}$. The best degradation rate of $\mathrm{NO}_{3}^{-}-\mathrm{N}$ and COD reached $66.88 \%$ and $82.85 \%$ respectively. Adding an external solar power to single chamber could enhance the treatment effect; specifically, $\mathrm{NO}_{3}^{-}-\mathrm{N}$ and COD removal rate reached $65.06 \%$ and $70.42 \%$ respectively, $6.14 \%$ and $9.73 \%$ higher than without external power.

\section{Keywords}

Microbial Fuel Cell, Groundwater, Nitrate

\section{Introduction}

Groundwater is widely used as one of the main sources of drinking water in most countries of the world [1]. In recent years, excessive use of chemical fertilizers and discharge of domestic and industrial waste water led to an

${ }^{*}$ Corresponding author. 
elevated of nitrate $\left(\mathrm{NO}_{3}^{-}-\mathrm{N}\right)$ content in groundwater [2] [3]. It will cause "blue baby syndrome" or even the potential effect on cancer when people drink ground water containing high level of $\mathrm{NO}_{3}^{-}-\mathrm{N}$ and nitrite $\left(\mathrm{NO}_{2}^{-}-\mathrm{N}\right)$ [4]-[6]. In order to reduce human health risks, the United States Environmental Protection Agency provided the maximum concentration limits for $\mathrm{NO}_{3}^{-}-\mathrm{N}$ and $\mathrm{NO}_{2}^{-}-\mathrm{N}$ in drinking water; they are respectively $10 \mathrm{mg} / \mathrm{L}$ and $1.0 \mathrm{mg} / \mathrm{L}$. EU and the World Health Organization provided the maximum concentration limits which are respectively $11.3 \mathrm{mg} / \mathrm{L}$ and $0.03 \mathrm{mg} / \mathrm{L}$ [7]-[9]. GB/T14848-93 in our country provided $\mathrm{NO}_{3}^{-}-\mathrm{N}$ in class III groundwater which should be less than $20 \mathrm{mg} / \mathrm{L}$. However, the groundwater in many parts far exceeded the top limit set by the agencies. Therefore, how economically and effectively remove the $\mathrm{NO}_{3}^{-}-\mathrm{N}$ in groundwater has become focused issues of concern both at home and abroad.

Although the removal of $\mathrm{NO}_{3}^{-}-\mathrm{N}$ in groundwater is more efficient by physicochemical methods such as ion exchange, reverse osmosis, and electro-dialysis, these methods need to be further treated and of high treatment costs. Biological denitrification is considered to be the most economical strategy among other conventional techniques [10]. However, traditional biological denitrification method is difficult to apply in practice due to formation the secondary pollution by addition of carbon sources [11]. Overview of the previous studies, this article will explore the treatment effect of nitrate and organic compounds by using microbial fuel cell (MFC) method.

\section{Materials}

Strains: laboratory strains derived from sludge in reflux tank of Wang Tong sewage treatment plant in Hefei and used for experiments after acclimatization and cultivation.

Concentration of every component in microbiological culture solution: $\mathrm{Na}_{2} \mathrm{HPO}_{4}, 4.0986 \mathrm{~g} / \mathrm{L} ; \mathrm{NaH}_{2} \mathrm{PO}_{4}$, $2.544 \mathrm{~g} / \mathrm{L} ; \mathrm{NH}_{4} \mathrm{Cl}, 0.31 \mathrm{~g} / \mathrm{L} ; \mathrm{KCl}, 0.13 \mathrm{~g} / \mathrm{L} ; \mathrm{C}_{6} \mathrm{H}_{12} \mathrm{O}_{6}, 0.5 \mathrm{~g} / \mathrm{L}$; Vitamin solution, $5 \mathrm{~mL} / \mathrm{L}$; Mineral solution, 12.5 $\mathrm{mL} / \mathrm{L}$.

Experimental apparatus: Ion chromatograph (CIC-100), Hash COD detector, Spectrophotometer, uv-spectrophotometer, $250 \mathrm{~mL}$ Polyethylene bottles, electronic scale.

\section{Double Chamber MFC and Single Chamber MFC}

Double chamber MFC: select the polyethylene bottle of $250 \mathrm{~mL}$ with sealing cap as cathode and anode chamber of double chamber MFC, add $80 \mathrm{~mL}$ acclimated sludge into anode chamber and fill it with culture solution, cathode chamber filled with artificial simulation of nitrate-contaminated groundwater, connect anode and cathode chamber with salt bridge of $1 \mathrm{~cm}$ in inner diameter and $25 \mathrm{~cm}$ in length, and series a certain resistance of resistor in external circuit. There are six groups of experiments, they are MFC0 - MFC5. The anode and cathode materials of MFC0, MFC1, MFC3, MFC4, MFC5 are stainless steel velvet as well as the anode material of MFC2, the cathode material of MFC2 is active carbon granule. Disconnect the anode and cathode of MFC0as a control group, connect the anode and cathode of MFC1 and MFC2 with copper wire and both are series a resistor of $1000 \Omega$ in external circuit, moreover, series a resistor of $100 \Omega$ in external circuit of MFC3, MFC4 and MFC5. The initial concentration of MFC0, MFC1, MFC2 and MFC3 is around $250 \mathrm{mg} / \mathrm{L}$, MFC4 is around $150 \mathrm{mg} / \mathrm{L}$, MFC5 is around $350 \mathrm{mg} / \mathrm{L}$. Keep the anode and cathode chamber of MFC0 - 5 in the anaerobic environment and take samples for analysis every three days, from that we can ensure the best parameters of the highest removal efficiency of nitrate.

Single chamber MFC: select the glass container of $20 \mathrm{~cm} \times 20 \mathrm{~cm} \times 35 \mathrm{~cm}$ in volume as the single chamber of MFC and filled with $3 \mathrm{~L}$ acclimated sludge and $5 \mathrm{~L}$ culture solution, as well as filled with nitrogen gas to maintain the anaerobic environment. The anode and cathode materials are stainless steel velvet, series a resistor of $1000 \Omega$ in external circuit. To explore the enhancement of nitrate and COD removal efficiency by series solar power in external circuit.

\section{Results and Discussion}

\subsection{Degradation of $\mathrm{NO}_{3}^{-}-\mathrm{N}$ in Cathode Chamber of Double Chamber MFC}

In experiments, the measured initial concentrations of $\mathrm{NO}_{3}^{-}-\mathrm{N}$ of MFC0 -3 are respectively $253.6 \mathrm{mg} / \mathrm{L}$, $245.1 \mathrm{mg} / \mathrm{L}, 246.6 \mathrm{mg} / \mathrm{L}$ and $251.8 \mathrm{mg} / \mathrm{L}$, the change of concentrations of $\mathrm{NO}_{3}^{-}-\mathrm{N}$ in cathode chamber of these four groups are shown in Figure 1. The measured initial concentrations of $\mathrm{NO}_{3}^{-}-\mathrm{N}$ of MFC4 and 
MFC5 are respectively $161.2 \mathrm{mg} / \mathrm{L}$ and $363.3 \mathrm{mg} / \mathrm{L}$. From MFC3, MFC4, MFC5 these three groups we can know the effect of initial concentration of $\mathrm{NO}_{3}^{-}-\mathrm{N}$ on removal efficiency, degradation curves of $\mathrm{NO}_{3}^{-}-\mathrm{N}$ under different initial concentrations are shown in Figure 2.

Figure 1 shows that the degradation effects of MFC1, MFC2 and MFC3 are obviously better than MFC0 which is disconnected of anode and cathode. It indicates that the connection of cathode and anode can promote the transfer of electrons from the anode to the cathode, $\mathrm{NO}_{3}^{-}-\mathrm{N}$ in cathode chamber produce reduction reaction after receiving electrons, and the effect is obvious in the first 15 days. The removal rate of $\mathrm{NO}_{3}^{-}-\mathrm{N}$ of MFC3 is $66.88 \%$ in 30 days, it is the highest in these three groups, followed by MFC1, MFC2. Thus, it can be seen that in the case of connecting the external circuit, using stainless steel velvet as cathod material, and selecting the external resistance of $100 \Omega$ work best on the degradation of $\mathrm{NO}_{3}^{-}-\mathrm{N}$. The averaged enitrification rate $(5.61 \mathrm{mg} / \mathrm{L} / \mathrm{d})$ of double chamber MFC in this article has a large difference than it was reported in literature (645.5 mg/L/d) [12]. The reason may be that the carbon tubular type Clauwaert built had a high specific surface area to provide more space for microorganisms, thus it was more conducive to microbial growth and electron transfer.

Figure 2 shows that different initial concentrations of $\mathrm{NO}_{3}^{-}-\mathrm{N}$ have the same degradation trend, especially obvious in the first 15 days. From the study of Manuel A. Rodrigo, the maximum power output of MFC related to the initial substrate concentration [13]. It is measured in experiments that the removal rates of $\mathrm{NO}_{3}^{-}-\mathrm{N}$ of

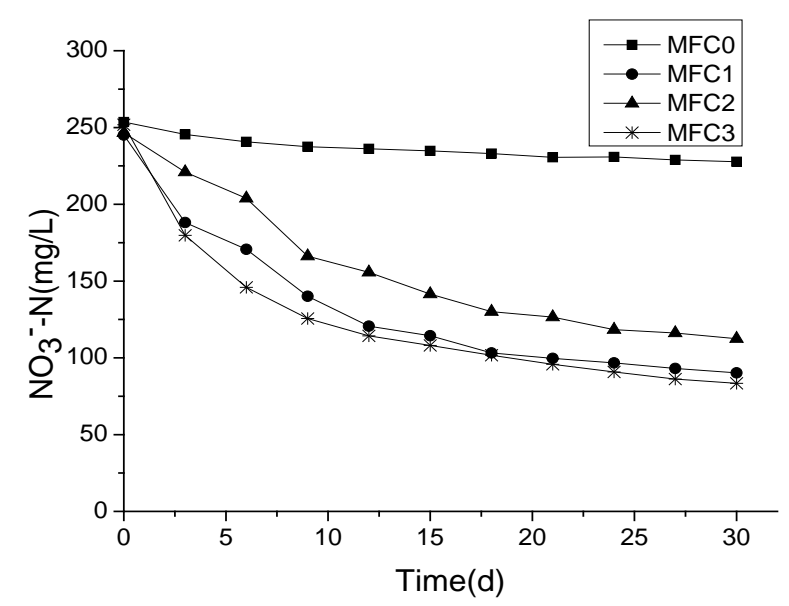

Figure 1. The changes of concentration of $\mathrm{NO}_{3}^{-}-\mathrm{N}$ in cathode chamber from MFC0 to MFC3.

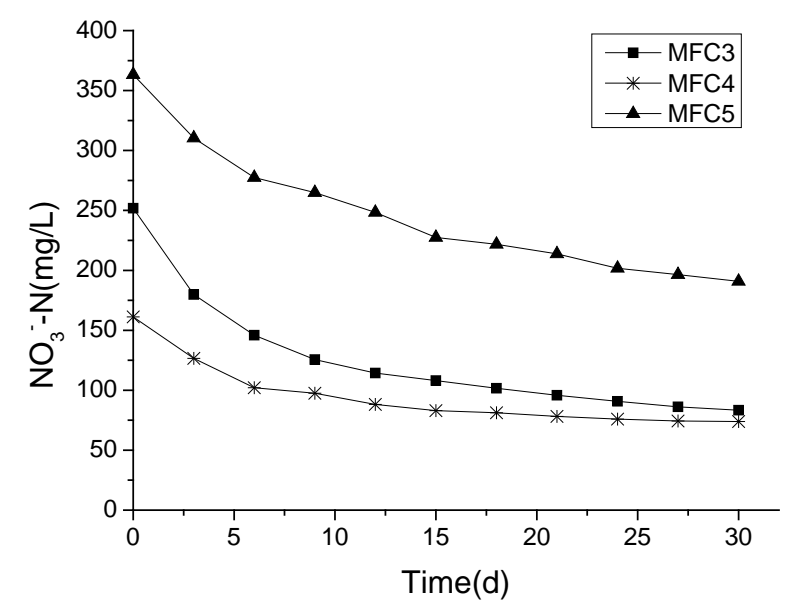

Figure 2. Degradation curves of $\mathrm{NO}_{3}^{-}-\mathrm{N}$ under different initial concentrations. 
MFC3, MFC4, and MFC5 within 30 days are respectively 66.88\%, 54.16\%, and 47.45\%. MFC3 has the highest removal rate, it indicates that under the same outside conditions, the initial concentration of $\mathrm{NO}_{3}^{-}-\mathrm{N}$ of around $250 \mathrm{mg} / \mathrm{L}$ could reach the highest removal rate.

\subsection{Degradation of COD in Anode Chamber of Double Chamber MFC}

Determining the concentration of $\mathrm{NO}_{3}^{-}-\mathrm{N}$ in cathode chamber as well as COD in anode chamber, the measured initial concentrations of COD in anode chamber of MFC0 - 5 are respectively $832 \mathrm{mg} / \mathrm{L}, 839 \mathrm{mg} / \mathrm{L}, 814$ $\mathrm{mg} / \mathrm{L}, 834 \mathrm{mg} / \mathrm{L}, 821 \mathrm{mg} / \mathrm{L}$, and $825 \mathrm{mg} / \mathrm{L}$. The changes of concentration of COD in anode chamber from MFC0 to MFC3 are showed in Figure 3, the degradation curves of COD under different initial concentrations of $\mathrm{NO}_{3}^{-}-\mathrm{N}$ are showed in Figure 4.

Figure 3 shows that both $\mathrm{NO}_{3}^{-}-\mathrm{N}$ and $\mathrm{COD}$ are decreasing with the increasing time, but the degradation trends are not exactly the same, COD continues to declining within 30 days, however, its degradation speed is much slower than that of $\mathrm{NO}_{3}^{-}-\mathrm{N}$. Besides, the degradation effect of MFC0 which is disconnected of anode and cathode is obviously worse than experimental groups, the removal rate of COD of MFC3 is $82.85 \%$ in 30 days, it is the highest in these experimental groups. It implies that in the case of connecting external circuit, using stainless steel velvet as cathode material, and selecting the external resistance of $100 \Omega$ can not only opti-

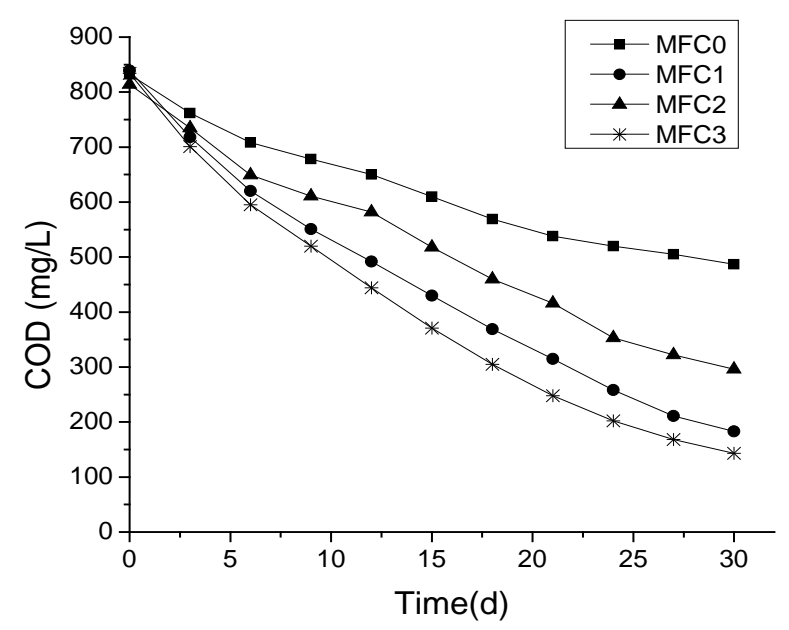

Figure 3. The changes of concentration of COD in anode chamber from MFC0 to MFC3.

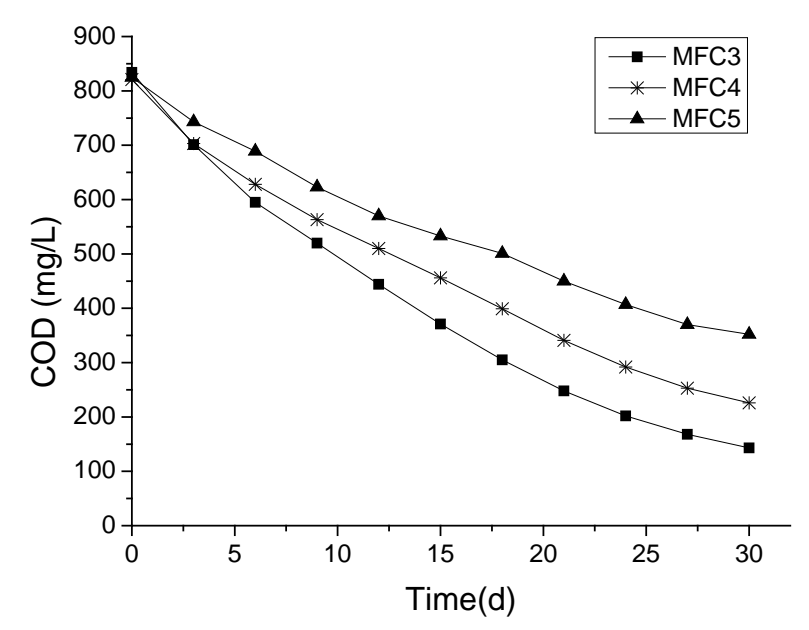

Figure 4. Degradation curves of COD under different initial concentrations of $\mathrm{NO}_{3}^{-}-\mathrm{N}$. 
mized the degradation of $\mathrm{NO}_{3}^{-}-\mathrm{N}$ but also the removal of COD.

Figure 4 shows that the degradation curves of COD in cathode chamber differ from each other in the case of different initial concentrations of $\mathrm{NO}_{3}^{-}-\mathrm{N}$. The removal rate of COD of MFC5 whose initial concentration of $\mathrm{NO}_{3}^{-}-\mathrm{N}$ of about $350 \mathrm{mg} / \mathrm{L}$ is only $57.33 \%$ within 30 days. However, the initial concentrations of $\mathrm{NO}_{3}^{-}-\mathrm{N}$ of MFC3 and MFC4 are respectively about $250 \mathrm{mg} / \mathrm{L}$ and $150 \mathrm{mg} / \mathrm{L}$, their removal rate of COD are respectively $82.85 \%$ and $72.47 \%$. It indicates that excessive initial concentration of $\mathrm{NO}_{3}^{-}-\mathrm{N}$ in cathode chamber is not conductive to the removal of COD in anode chamber, the highest removal rate of COD in anode chamber occurs in the condition of which initial concentration of $\mathrm{NO}_{3}^{-}-\mathrm{N}$ range from $150 \mathrm{mg} / \mathrm{L}$ to $250 \mathrm{mg} / \mathrm{L}$. Compare the result with the MBR system reported by Wang [14], our system is simpler and easy to maintain.

In addition, due to the obvious effect of experiments within the first 15 days, the data of the 15th day is selected for analysis. The degradation rate of $\mathrm{NO}_{3}^{-}-\mathrm{N}$ of MFC0 - MFC5 are respectively $7.42 \%, 53.33 \%$, $42.62 \%, 57.07 \%, 48.49 \%$, and $37.38 \%$. The removal rate of COD are respectively $26.68 \%, 48.75 \%$, $36.36 \%$, $55.52 \%, 44.46 \%$, and $35.39 \%$. The specific comparison is showed in Figure 5.

Figure 5 demonstrates that the experimental groups of MFC1 - 5 work better than the control group of MFC0, it indicates that connecting external circuit of anode and cathode is good for reaction. In all experimental groups, MFC3 has the highest removal rates of both $\mathrm{NO}_{3}^{-}-\mathrm{N}$ and COD within the first 15 days. All above, the experiment works better in the condition of connecting external circuit, using stainless steel velvet as cathode material, selecting the external resistance of $100 \Omega$, and making the initial concentration of $\mathrm{NO}_{3}^{-}-\mathrm{N}$ of about 250 $\mathrm{mg} / \mathrm{L}$.

\subsection{Degradation of $\mathrm{NO}_{3}^{-}-\mathrm{N}$ and COD in Single Chamber MFC}

Initial concentration of $\mathrm{NO}_{3}^{-}-\mathrm{N}$ and COD are respectively about $250 \mathrm{mg} / \mathrm{L}$ and $820 \mathrm{mg} / \mathrm{L}$, this experiment keeps the single chamber in the anaerobic condition, makes the external circuits respectively in the status of open circuit, normal circuit, and adding an extra power, then measures the degradation effects of $\mathrm{NO}_{3}^{-}-\mathrm{N}$ and COD. Experimental results are showed in Figure 6 and Figure 7.

It can be seen from Figure 6 and Figure 7 that the degradation effect of adding an extra power in external circuit is obviously better than the status of open circuit and normal circuit. Its removal rates of $\mathrm{NO}_{3}^{-}-\mathrm{N}$ and COD are respectively $65.06 \%$ and $70.42 \%, 6.14 \%$ and $9.73 \%$ higher than the status of normal circuit. On the one hand, it implies the microorganisms in single chamber produce electrons by consuming organic matter, the electrons pass through the external circuit to the cathode to promote denitrification reaction; On the other hand, the results show that single chamber MFC, without proton exchange membrane, is able to remove $\mathrm{NO}_{3}^{-}-\mathrm{N}$ and COD in wastewater in partnership, and add an extra power in external circuit could enhance the reaction. In the study of $\mathrm{Yi}$ [15], it indicates that higher $\mathrm{NO}_{3}^{-}-\mathrm{N}$ concentrations inhibit the electronic output of biodegradation process. It seems to be valuable to continue the study by reducing the initial concentration of $\mathrm{NO}_{3}^{-}-\mathrm{N}$.

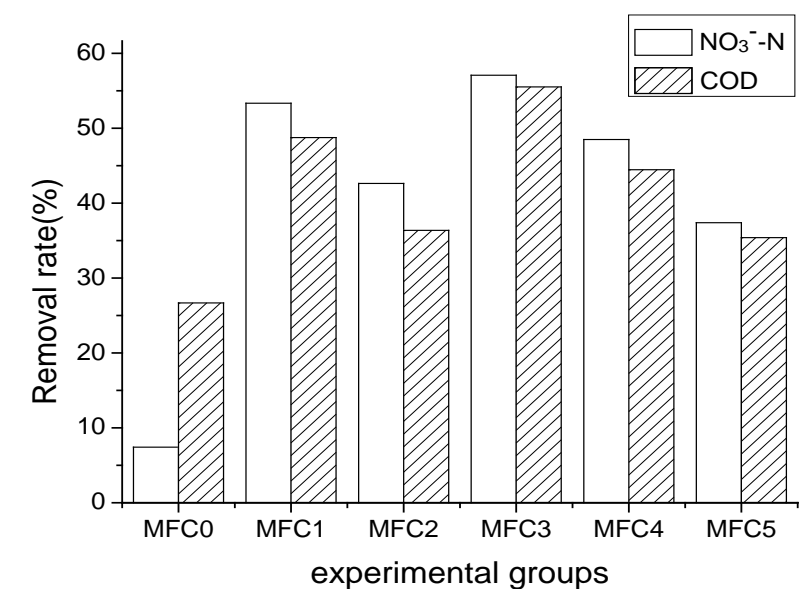

Figure 5. The comparison chart of $\mathrm{NO}_{3}^{-}-\mathrm{N}$ and COD reduction rate in 15 days. 


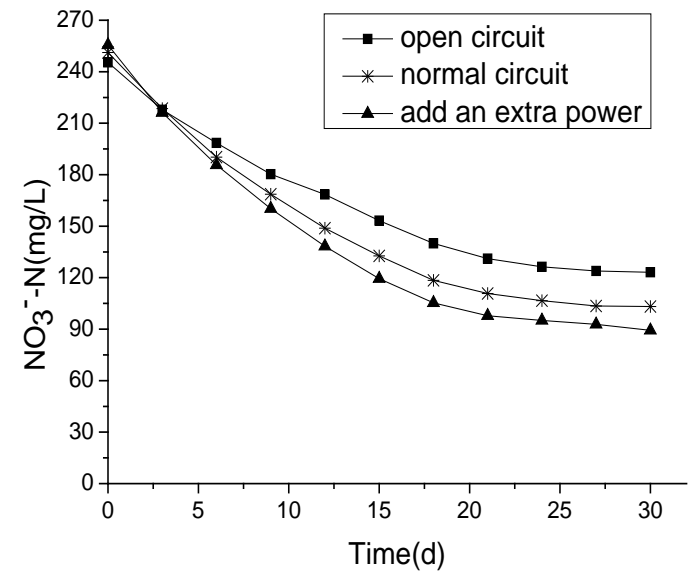

(a)

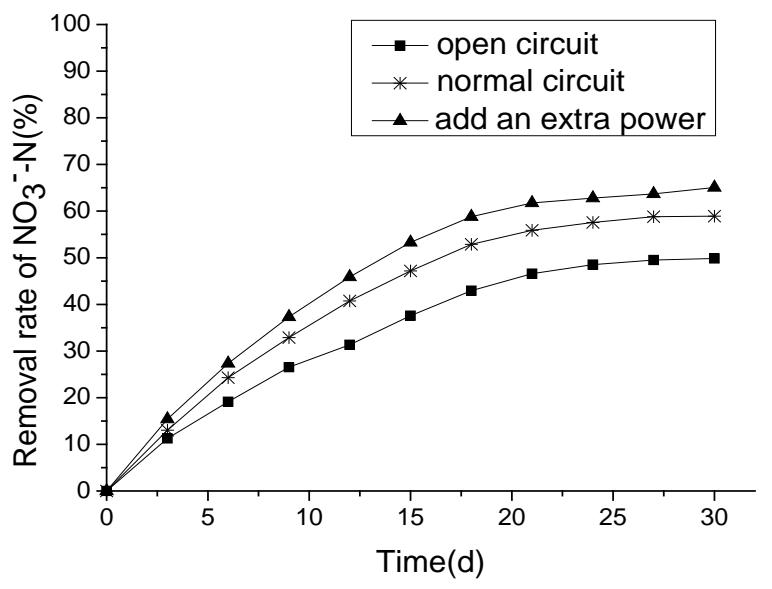

(b)

Figure 6. The removal of $\mathrm{NO}_{3}^{-}-\mathrm{N}$ with time change. (a) The concentration curves of $\mathrm{NO}_{3}^{-}-\mathrm{N}$; (b) the removal rate of $\mathrm{NO}_{3}^{-}-\mathrm{N}$.

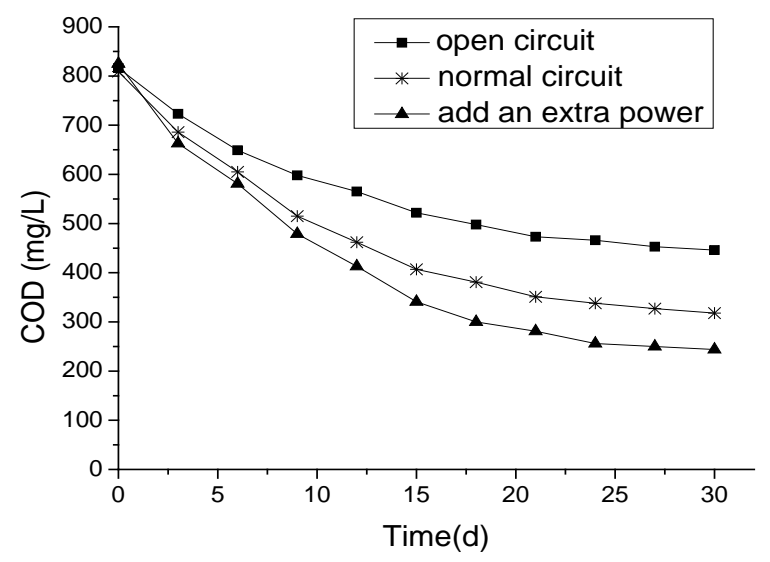

(a)

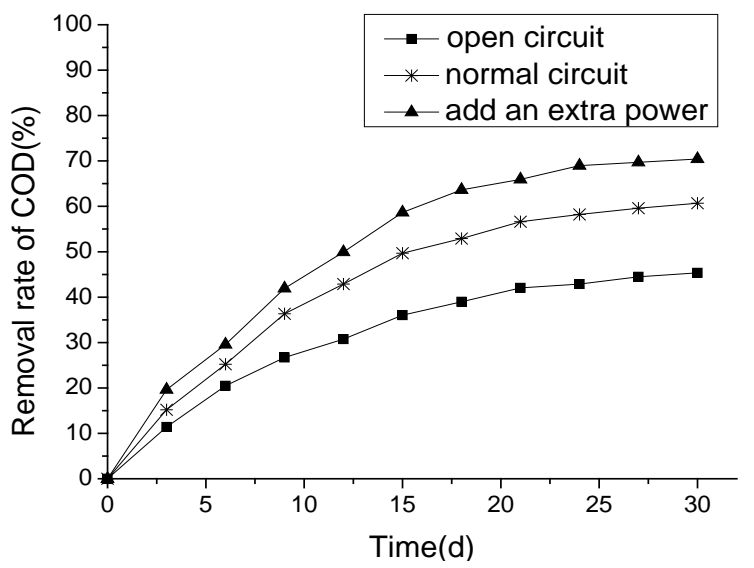

(b)

Figure 7. The removal of COD with time change. (a) The concentration curves of COD; (b) the removal rate of COD.

Determine the concentrations of $\mathrm{NO}_{3}^{-}-\mathrm{N}$ and COD in wastewater and simultaneously determine the content of $\mathrm{NO}_{2}^{-}-\mathrm{N}$ due to the denitrification process has the potential to generate $\mathrm{NO}_{2}^{-}-\mathrm{N}$. The results can be shown in Figure 8.

Figure 8 shows that the accumulation of $\mathrm{NO}_{2}^{-}-\mathrm{N}$ in these three groups is small. The microorganisms in single chamber MFC produce electrons by consuming organic matter. The $\mathrm{NO}_{3}^{-}-\mathrm{N}$ occurred the following reduction reaction as an electron acceptor:

$$
\begin{aligned}
& 2 \mathrm{NO}_{3}^{-}+4 \mathrm{H}^{+}+4 \mathrm{e}^{-} \rightarrow 2 \mathrm{NO}_{2}^{-}+2 \mathrm{H}_{2} \mathrm{O} \\
& 2 \mathrm{NO}_{2}^{-}+4 \mathrm{H}^{+}+2 \mathrm{e}^{-} \rightarrow 2 \mathrm{NO}+2 \mathrm{H}_{2} \mathrm{O} \\
& 2 \mathrm{NO}+2 \mathrm{H}^{+}+2 \mathrm{e}^{-} \rightarrow \mathrm{N}_{2} \mathrm{O}+\mathrm{H}_{2} \mathrm{O} \\
& \mathrm{N}_{2} \mathrm{O}+2 \mathrm{H}^{+}+2 \mathrm{e}^{-} \rightarrow \mathrm{N}_{2}+\mathrm{H}_{2} \mathrm{O}
\end{aligned}
$$

\section{Conclusions}

The best degradation effect of $\mathrm{NO}_{3}^{-}-\mathrm{N}$ and COD in double chamber MFC is in the condition of using stainless steel velvet as cathod and anode materials and selecting the external resistance of $100 \Omega$. In this experiment, 


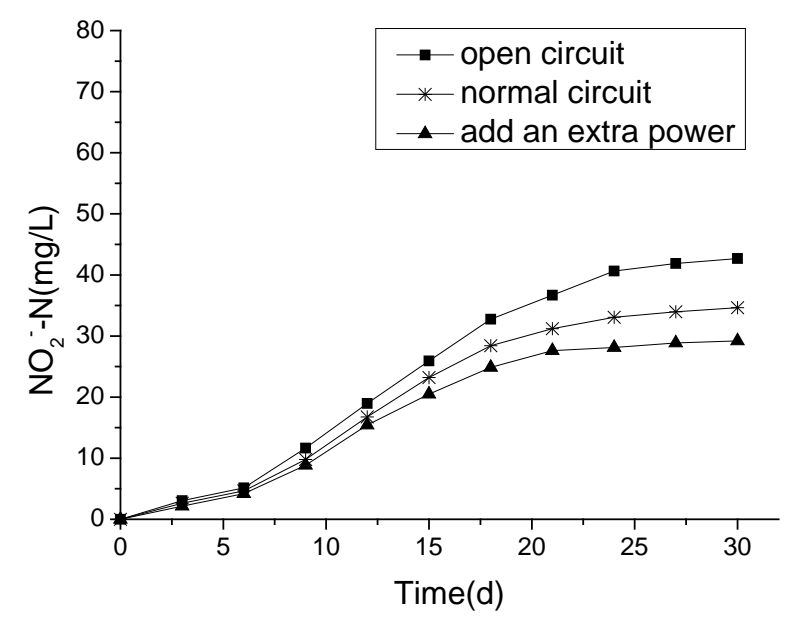

Figure 8. The removal of $\mathrm{NO}_{2}^{-}-\mathrm{N}$ with time change.

the highest removal rates of $\mathrm{NO}_{3}^{-}-\mathrm{N}$ and COD are respectively $66.88 \%$ and $82.85 \%$ with the initial concentration of $\mathrm{NO}_{3}^{-}-\mathrm{N}$ in cathode chamber of about $250 \mathrm{mg} / \mathrm{L}$.

Single chamber MFC, without proton exchange membrane, is able to remove $\mathrm{NO}_{3}^{-}-\mathrm{N}$ and COD in wastewater in partnership. Adding an extra power in external circuit could enhance the reaction, as the result shows that its removal rates of $\mathrm{NO}_{3}^{-}-\mathrm{N}$ and COD are respectively $65.06 \%$ and $70.42 \%, 6.14 \%$ and $9.73 \%$ higher than the normal circuit. The single chamber MFC has a wide application with the advantages of simple structure, low operating cost and high treatment effect.

\section{References}

[1] Tong, S., Zhang, B.G., Feng, C.P., Zhao, Y.X., Chen, N., Hao, C.B., Pu, J.Y. and Zhao. L.W. (2013) Characteristics of Heterotrophic/Biofilm-Electrode Autotrophic Denitrification for Nitrate Removal from Groundwater. Bioresource Technology, 148, 121-127. http://dx.doi.org/10.1016/j.biortech.2013.08.146

[2] Zhang, Y.F. and Angelidaki, I. (2013) A New Method for in Situ Nitrate Removal from Groundwater Using Submerged Microbial Desalinatione-Denitrification Cell (SMDDC). Water Research, 47, 1827-1836. http://dx.doi.org/10.1016/j.watres.2013.01.005

[3] Park, H.I., Kim, D.K., Choi, Y. and Pak, D. (2005) Nitrate Reduction Using an Electrode Asdirect Electron Donor in a biofilm-Electrode Reactor. Process Biochem, 40, 3383-3388. http://dx.doi.org/10.1016/j.procbio.2005.03.017

[4] Camargo, J.A. and Alonso, A. (2006) Ecological and Toxicological Effects of Inorganic Nitrogen Pollution in Aquaticeco Systems: Aglobal Assessment. Environment International, 32, 831-849.

[5] Fewtrell, L. (2004) Drinking-Water Nitrate, Methemoglobinemia, and Global Burden of Disease: A Discussion. EnvironmentalHealth Perspectives, 112, 1371-1374. http://dx.doi.org/10.1289/ehp.7216

[6] Suthar, S., Bishnoi, P., Singh, S., Mutiyar, P.K., Nema, A.K. and Patil, N.S. (2009) Nitrate Contamination in Groundwater of Some Rural Areas of Rajasthan. Journal of Hazardous Materials, 171, 189-199.

[7] United States Environmental Protection Agency. National Primary Drinking Water Standards. USEPA Office of Water, Washington DC, Doc. 810-F-94-001

[8] WHO (2004) Guidelines for Drinking Water Quality. World Health Organization, Geneva.

[9] Xia, S.Q., Zhong, F.H., Zhang, Y.H., Li, H.X. and Yang, X. (2009) Bio-Reduction of Nitrate from Groundwater Using a Hydrogen-Based Membrane Biofilm Reactor. Journal of Environmental Sciences, 22, 257-262. http://dx.doi.org/10.1016/S1001-0742(09)60102-9

[10] Liu, S.-J., Zhao, Z.-Y., Li, J., Wang, J. and Qi, Y. (2013) An Anaerobic Two-Layer Permeable Reactive Biobarrier for the Remediation of Nitrate Contaminated Groundwater. Water Reasearch, 47, 5977-5985. http://dx.doi.org/10.1016/j.watres.2013.06.028

[11] Sarina, J.E. and David, E.R. (2004) Drinking Water Denitrification Using a Membrane Bioreactor. Water Research, 38, 3225-3232. http://dx.doi.org/10.1016/j.watres.2004.04.019

[12] Clauwaert, P., Rabaey, K., Aelterman, P., De Schamphelaire, L., Pham, T. H., Boeckx, P., Boon, N. and Verstraete, W. 
(2007) Biological Denitrification in Microbial Fuel Cells. Environmental Science and Technology, 41, 3354-3360. http://dx.doi.org/10.1021/es062580r

[13] Rodrigo, M.A., Canizares, P., Lobato, J., Paz, R., Szea, C. and Linares, J.J. (2007) Production of Electricity from the Treatment of Urban Waste Water Using a Microbial Fuel Cell. Journal of Power Sources, 169, 198-204. http://dx.doi.org/10.1016/j.jpowsour.2007.01.054

[14] Wang, Y.K., Sheng, G.P., Li, W.W., Huang, Y.X., Yu, Y.Y., Zeng, R.J., et al. (2011) Development of Anovel Bioelectrochemical Membrane Reactor for Wastewater Treatment. Environmental Science \& Technology, 45, 9256-9261. http://dx.doi.org/10.1021/es2019803

[15] Yi, T. and Harper, W. (2009) The Effect of Nitrate and Sulfate on Mediator-Less Microbial Fuel Cells with High Internal Resistance. Water Environment Research, 81, 2320-2328. http://dx.doi.org/10.2175/193864709793955816 